\title{
Nutrient composition of Algerian strawberry-tree fruits (Arbutus unedo L.)
}

\section{Noureddine Boussalah ${ }^{1}$, , Djamal Boussalah ${ }^{2}$, Laura Cebadera-Miranda ${ }^{3}$, Virginia Fernández-Ruiz ${ }^{3}$, Lillian Barros ${ }^{4}$, Isabel C.F.R. Ferreira ${ }^{4}$, Maria Cortes Sanchez Mata ${ }^{3}$ and Khodir Madani ${ }^{1}$}

${ }^{1}$ Laboratoire de Biomathématiques, Biophysique, Biochimie, et Scientométrie (L3BS), Faculté des Sciences de la Nature et de la Vie, Université de Bejaia, 06000 Bejaia, Algeria.

${ }^{2}$ Institut National de Criminalistique et de Criminologie de la Gendarmerie Nationale (INCC-GN), Foret de Bouchaoui, 16002 Cheraga, Algeria

${ }^{3}$ Dpto, Nutrición y Bromatología II, Facultad de Farmacia, Universidad Complutense de Madrid (UCM), Pza Ramón y Cajal, s/n, E-28040 Madrid, Spain

${ }^{4}$ Mountain Research Centre (CIMO), ESA, Polytechnic Institute of Bragança, Campus de Santa Apolónia, 1172, 5300-253 Bragança, Portugal

\begin{abstract}
Introduction. Arbutus unedo L. (strawberry-tree fruit) is indigenous plant in North Africa with few published works about the composition of its fruits. For their valorization, morphological and chemical characterizations were carried out for two harvesting seasons of four different areas of Algeria. Materials and methods. Wild strawberry-tree fruits were collected in four different sites located in Tell Atlas, and two different seasons. Fruit size and shape, $\mathrm{pH}$, titratable acidity, moisture, total available carbohydrate (TAC), soluble sugars, dietary fiber, protein, lipid, ash, fatty acids and mineral composition (K, Na, $\mathrm{Ca}, \mathrm{Mg}, \mathrm{Fe}, \mathrm{Cu}, \mathrm{Mn}, \mathrm{Zn}, \mathrm{Ni}$ and $\mathrm{Cd}$ ) were determined. Results and discussion. Fruit contents (in $\mathrm{g} \mathrm{kg}^{-1}$ ) varied between $637.3 \pm 33.8$ to $741.3 \pm 12.0$, $126.8 \pm 11.1$ to $189.3 \pm 4.1,22.6 \pm 2.2$ to $35.5 \pm 2.1,5.1 \pm 0.3$ to $8.8 \pm 0.5$ for moisture, TAC, protein and lipid, respectively. For iron, fruit weight and polyunsaturated fatty acids (PUFA), the contents varied between $7.01 \pm 0.15$ to $17.24 \pm 0.74 \mathrm{mg} \mathrm{kg}^{-1}$ of fruit, $4.91 \pm 1.58$ to $6.76 \pm$ $2.04 \mathrm{~g}$ and $56.34 \pm 1.37$ to $68.18 \pm 0.14 \%$ of lipid, respectively. Conclusion. This study provides original data about the morphological and chemical composition of strawberry-tree fruits from Algeria. The results show that the fruits can be essentially a potential source of dietary fiber, PUFA and iron.
\end{abstract}

Keywords: Algeria; Arbutus unedo L. (strawberry-tree fruit); morphological characterization of fruit; food composition; wild fruit

\section{Composition nutritionnelle des fruits de l'arbousier Algérien (Arbutus unedo L.).}

Résumé - Introduction. Arbutus unedo L. (Arbousier) est une plante indigène en Afrique du Nord avec peu de travaux publiés sur la composition de ses fruits. Pour leur valorisation, une caractérisation morphologique et chimique a été réalisée pour quatre régions différentes de l'Algérie et deux saisons de récolte. Matériel et méthodes. Les fruits sauvages ont été récoltées de quatre sites de l'Atlas Tellien sur deux saisons différentes. Taille et forme du

·Corresponding author: noureddine.boussalah@univ-bejaia.dz 
fruit, $\mathrm{pH}$, acidité titrable, humidité, glucides totaux disponibles (GTD), sucres solubles, fibres alimentaires, protéines, lipides, cendres, acides gras et composition minérale ( $\mathrm{K}, \mathrm{Na}, \mathrm{Ca}, \mathrm{Mg}$, $\mathrm{Fe}, \mathrm{Cu}, \mathrm{Mn}, \mathrm{Zn}, \mathrm{Ni}$ et $\mathrm{Cd}$ ) ont été déterminés. Résultats et discussion. Les teneurs des fruits $\left(\mathrm{en}_{\mathrm{g} \mathrm{kg}}{ }^{-1}\right)$ ont varié de $637.3 \pm 33.8$ à $741.3 \pm 12.0$, de $126.8 \pm 11.1$ à $189.3 \pm 4.1$, de $22.6 \pm$ 2.2 à $35.5 \pm 2.1$ et de $5.1 \pm 0.3$ à $8.8 \pm 0.5$ pour l'humidité, les GTD, les protéines et les lipides, respectivement. Pour le fer, le poids des fruits et les acides gras polyinsaturés (AGPI), les teneurs ont varié de $7.01 \pm 0.15$ à $17.24 \pm 0.74 \mathrm{mg} \mathrm{kg}^{-1}$ de fruits, de $4.91 \pm 1.58$ à $6.76 \pm$ $2.04 \mathrm{~g}$ et de $56.34 \pm 1.37$ à $68.18 \pm 0.14 \%$ de lipides, respectivement. Conclusion. Cette étude fournit des données originales sur la composition morphologique et chimique des fruits de l'arbousier d'Algérie. Les résultats montrent que les fruits peuvent être essentiellement une source potentielle de fibres alimentaires, de AGPI et de fer.

Mots-clés : Algérie ; Arbutus unedo L. (fruit de l'arbousier) ; caractérisation morphologique des fruits ; composition des aliments ; fruit sauvage.

\section{Significance of this study}

What is already known on this subject?

- There is many published studies of Arbutus unedo L. fruits from European countries, and despite the wide spread of this species in the Algerian Tell Atlas mountains, these wild fruits remain unknown in terms of composition.

What are the new findings?

- This work is the first morphological and chemical characterization of Algerian Arbutus unedo L. fruits. They are a good source of dietary fiber, unsaturated fatty acids and iron. In addition, three fruit shapes have been identified: round (51.6\%), flat (40.3\%) and elongate shape (8.1\%).

What is the expected impact on horticulture?

- Fruit morphology and composition data may be valuable information to be used for trials devoted to adaptation to growing conditions, breeding programs, Food Composition Databases or developing new industrial foods 


\section{Introduction}

The strawberry-tree (Arbutus unedo L., Ericaceae) is a shrub or small tree that can reach up to 9-12 m and found in all the Mediterranean basin (excluding Egypt and Libya). It has a dense evergreen foliage with glossy green, white bell-shaped flowers (Mhamdi Takrouni et al., 2012; Sánchez-Mata and Tardío, 2016) and a red fleshy spherical fruits with 2-3 cm diameter at maturity, with the presence of prominences that giving them a spiky shape. At advanced ripening stage, it has a sweet taste and it has been reported as rich in fermentable sugars, dietary fiber, minerals, unsaturated fatty acids and several antioxidant compounds including vitamins (vitamin C, vitamin E, carotenoids, etc.) (Alarcão-E-Silva et al., 2001; Ayaz et al., 2000; Özcan and Hacıseferoğulları, 2007; Pallauf et al., 2008; Ruiz-Rodríguez et al., 2011; Ruiz-Rodríguez et al., 2014a) and various phenolic compounds, such as phenolic acids (gallic acid, protocatechuic acid, gentisic acid, $p$-hydroxybenzoïc acid, vanillic acid and $m$-anisic acid), arbutine (Ayaz et al., 2000), proanthocyanidins and flavonoids as myricetin-3xyloside, quercetin-3-rutinoside, quercetin-3-xyloside,quercetin-3-rhamnoside and anthocyanins (glycosides of cyanidin and delphinidin) (Pallauf et al., 2008).

The fruits are edible and acquire a pleasant flavor only at advanced maturity stage, which limits their consumption as fresh fruits. Besides they are usually processed into alcoholic beverages (wines, liqueurs and brandies), jams, marmalades and jellies (Alarcão-E-Silva et al., 2001; Pallauf et al., 2008). In addition, it has been reported that in traditional medicine the fruits have shown antiseptic, diuretic, and laxative effects (Pallauf et al., 2008) and they are used to treat gastritis (Cornara et al., 2009; Leonti et al., 2009; Oliveira et al., 2011b), urological, dermatological, cardiovascular (Leonti et al., 2009) and kidney diseases (El-Hilaly et al., 2003), but all these uses remain more as traditional habits than having economical purposes (Celikel et al., 2008). That is why, A. unedo fruits can be valorized through other new uses, such as making non-alcoholic beverages, by incorporating them into yogurts, dessert fillings and cereals products or as a source of bioactive compounds in food supplements and nutraceuticals (Barros et al., 2010; Ruiz-Rodríguez et al., 2011). This would lead to the integration of this species in sustainable development projects to become an income resource for the farmers, which will participate in the preservation of forests and mountain ecosystems (González et al., 2011). For those purposes, the information on the composition of strawberry tree fruits might be useful for consumers and food technologists (Ruiz-Rodríguez et al., 2011).

In the literature, apart of the genetic diversity of strawberry-tree (Mhamdi Takrouni et al., 2012; Mhamdi Takrouni and Boussaid, 2010), several studies of biological activity of leaves (Ruiz-Rodríguez et al., 2011) and antioxidant activity of fruits (Barros et al., 2010), only a few works on nutritional aspects has been reported (Ruiz-Rodríguez et al., 2011).

On the other hand, it is widely known that natural food resources are subjected to high natural variability depending on genetic and environmental conditions of growing, particularly in wild fruits (Maieves et al., 2015; Ruiz-Rodríguez et al., 2014b). In this context, although some European fruits have been previously studied, very little is known about the chemical composition of strawberry-tree fruits from African origin (Sánchez-Mata and 
Tardío, 2016), apart from some work about bioactive properties such as Allane and Benamara (2010).

For that reason, the aim of this study is to provide original data for the characterization of strawberry-tree fruits from North-Africa (Algerian Tell Atlas Mountains), including natural variability (location and season) which is necessary to achieve representative data to contribute to fruit composition knowledge. This main objective can be addressed by the following specific objectives: i) study of morphology of strawberry-tree fruits (fruit weight, size and shape); ii) study of physicochemical parameters ( $\mathrm{pH}$, titratable acidity, moisture); iii) study of nutrient composition of strawberry-tree fruits (available carbohydrate, soluble sugars, proteins, dietary fiber, lipids, ash, fatty acids and mineral composition).

The hypothesis of this work is that, as A. unedo L. is widespread in Algerian forests and in the past, it has been an important source of nutrients for rural populations, nowadays it can be also a good source of nutrients, even taking into account the natural variability linked to fruits composition.

\section{Materials and methods}

\subsection{Sampling}

Arbutus unedo L. fruits were harvested from four sampling areas, situated on the Tell Atlas Mountains (Northern of Algeria) (Figure 1). Three areas are located at nearly 400, 200 and $150 \mathrm{Km}$ to the east of Algiers: at Skikda (SK) (latitude $36^{\circ} 46^{\prime} 34.78 \mathrm{~N}$, longitude $6^{\circ} 59^{\prime} 30.88 \mathrm{E}$ and altitude $240 \mathrm{~m}$ ), Bordj-Mira (BM) (latitude $36^{\circ} 33^{\prime} 29.25 \mathrm{~N}$, longitude $5^{\circ} 18^{\prime} 48.66 \mathrm{E}$ and altitude $220 \mathrm{~m}$ ) and Adekar (AD) (latitude 36 $46^{\circ} 13.56 \mathrm{~N}$, longitude $4^{\circ} 40^{\prime} 49.58 \mathrm{E}$ and altitude $980 \mathrm{~m}$ ), respectively. The last area was at Medea (MD) (latitude $36^{\circ} 20^{\prime} 49.15^{\prime \prime} \mathrm{N}$, longitude $2^{\circ} 40^{\prime} 32.86^{\prime \prime} \mathrm{E}$ and altitude $854 \mathrm{~m}$ ) located at $80 \mathrm{Km}$ to the southwest of Algiers.

According to world reference base for soil resource, Adekar and Skikda soils are classified as haplic luvisol and albic luvisol, which are slightly acid and clay-rich soils, respectively. While, Medea and Bordj-Mira soils are classified as a haplic calcisol (with high accumulation of calcium carbonate) (Jones et al., 2013).

Two kg fruit (about 350 berries gathered from 15, 17, 18 and 20 trees from Sk, BM, MD and $\mathrm{AD}$, respectively) for each area were harvested in natural forests at their optimal ripening status, with red color, soft flesh and a healthy external appearance, in November-December of 2012 and 2013. The sample was prepared according to the procedures recommended by Greenfield and Southgate (2003) to obtain composition data of wild fruit samples. The samples were transported to the laboratory in the same day in cooler box at $4{ }^{\circ} \mathrm{C}$. Each sample was divided into two equal parts: the first one was used immediately for the determination of moisture content, $\mathrm{pH}$, titratable acidity and morphological characteristics of the fruits, and the 
second one was washed with distilled water and lyophilized (LyoQuest-55, Telstar, Terrassa, Spain).

\subsection{Determination of morphological parameters}

Fruit size and shape were determined from a randomly selected weight of $250 \mathrm{~g}$ from each area. The weight, the length (L) and the diameter (D) of each berry were determined using an analytical balance and a digital caliper (Instruments Horaires MOINEAU, ChefBoutonne, France). Fruit weight and fruit shape index (FSI) was expressed as reported by Brewer et al. (2006) and Tromp (1990) as the L/D ratio.

\subsection{Moisture content, $\mathrm{pH}$ and titratable acidity}

Moisture content of the fruits was determined on fresh berries before washing. Fruits were blended using home mixer, and an amount of two $\mathrm{g}$ of homogenized fruits were dried until constant weight at $103 \pm 2{ }^{\circ} \mathrm{C}$ following AOAC 930.04 method (Horwitz and Latimer, 2005).

The homogenized sample was diluted with distilled water $(1: 10, \mathrm{w} / \mathrm{v})$ and used for the $\mathrm{pH}$ (pH-meter 211 Microprocessor, Hanna Instruments, Tanneries, France) and for the titratable acidity measurement $(0.1 \mathrm{~N} \mathrm{NaOH})$ until $\mathrm{pH}$ of 8.1 (Ruiz-Rodríguez et al., 2011). Titratable acidity was expressed as $\mathrm{g}$ of malic acid equivalents per $\mathrm{Kg}$ of fresh weight.

\subsection{Total available carbohydrate (TAC)}

Total available carbohydrate was determined on freeze-dried samples by a colorimetric method using perchloric acid hydrolysis and anthrone reagent (Osborne and Voogt, 1986). The absorbance was measured at $630 \mathrm{~nm}$ on a UV/Vis Spectrometer EZ 210 (Perkin Elmer, Waltham, MA, USA) equipped with Lambda software PESSW ver. 1.2. A calibration curve was made by using the glucose as standard with a concentration range between 20 to $120 \mu \mathrm{g}$ $\mathrm{mL}^{-1}$.

\subsection{Soluble sugars}

An aliquot of freeze-dried sample ( $0.5 \mathrm{~g})$ was used to quantify soluble sugars content by high performance liquid chromatography with refractive index detector (HPLC-RID) method as described previously by Sánchez-Mata et al. (1998). The HPLC system was equipped with PU II isocratic pumping system (Micron Analitica, SA, Spain), a U6K Waters injector, a differential refractometer R401 detector (Jasco, Madrid, Spain) and a Luna $5 \mu \mathrm{NH}_{2} 100 \mathrm{R}$ column $(250 \times 4.60 \mathrm{~mm})$ (Phenomenex, Torrance, CA, USA). The mobile phase was acetonitrile:water (80:20), at a flow rate of $0.8 \mathrm{~mL} \mathrm{~min}^{-1}$. Chromatograms were processed using Cromanec XP software (Micronec, Madrid, Spain). The quantification of the chromatographic peaks was obtained by external standards curves of $\mathrm{D}(-)$-fructose, $\mathrm{D}(+)$ glucose, $\mathrm{D}(+)$-sucrose and $\mathrm{D}(+)$-maltose in a concentration range of $0.1-2 \mathrm{mg} \mathrm{mL}^{-1}$. 


\subsection{Dietary fiber}

Dietary fiber content was determined by an enzymatic-gravimetric method according to AOAC 993.19 method for insoluble dietary fiber (IDF) and AOAC 991.42 method for the soluble dietary fiber (SDF). Freeze-dried sample $(0.5 \mathrm{~g})$ was digested with a thermostable $\alpha-$ amylase, protease and amyloglucosidase. The final residue was filtered, washed with distilled water, ethanol 95\% (v/v) and then with absolute acetone. After drying, the residue was weighed. The total dietary fiber (TDF) is expressed as the sum of IDF and SDF (Horwitz and Latimer, 2005).

\subsection{Protein content}

Protein content was carried out by the Kjeldahl method (AOAC 955.04). The total nitrogen content was converted in to protein content by a conversion factor of 6.25 (Horwitz and Latimer, 2005) and the protein content was expressed as g protein $\mathrm{kg}^{-1}$ fresh fruit.

\subsection{Lipid content}

Lipid content was determined gravimetrically according to the method AOAC 920.39 with absolute diethyl ether solvent at $60^{\circ} \mathrm{C}$ for 6 hours using Soxhlet extractor. The solvent was evaporated and containers were removed and dried at $100{ }^{\circ} \mathrm{C}$ for 30 minutes, cooled and weighted (Horwitz and Latimer, 2005).

\subsection{Fatty acids composition}

Fatty acids composition was obtained by gas chromatography coupled to a flame ionization detector, following the method described by Barros et al. (2008). The lipids extracted previously by Soxhlet were converted to the corresponding methyl esters with $5 \mathrm{~mL}$ of methanol/sulfuric acid/toluene $(2: 1: 1, \mathrm{v} / \mathrm{v} / \mathrm{v})$, during at least $12 \mathrm{~h}$ in a bath at $50{ }^{\circ} \mathrm{C}$. The chromatography apparatus was a Trace GC Ultra (Thermo Fisher Scientific, Waltham, USA) equipped with a split/splitless injector, an autosampler TriPlus, an FID detector at a temperature of $250^{\circ} \mathrm{C}$ and a Tr-wax capillary column $(30 \mathrm{~m} \times 0.32 \mathrm{~mm} \mathrm{ID} \times 0.25 \mathrm{~mm}$, Thermo Fisher Scientific). The temperature program of the column was at $50{ }^{\circ} \mathrm{C}$ for $2 \mathrm{~min}$, and then increased with a slope of $4{ }^{\circ} \mathrm{C} \min ^{-1}$ up to $220{ }^{\circ} \mathrm{C}$, maintained at $220{ }^{\circ} \mathrm{C}$ for $15 \mathrm{~min}$. The carrier gas was helium with a flow rate of $4.0 \mathrm{~mL} \mathrm{~min}^{-1}$ at a pressure $(0.61 \mathrm{bar})$. The injection volume was $1 \mu \mathrm{L}$ in split mode $(1: 40)$ at $250^{\circ} \mathrm{C}$. Fatty acids identification was made by the comparing the retention time of peaks from samples with standards (Supelco 37 component fatty acid methyl ester mix, standard 47885-U, Sigma-aldrich, St. Louis, MO, USA). The results were acquired and processed using ChromQuest 4.2 software (Thermo Quest, San Jose, CA, USA) and expressed as relative percentage of each fatty acid.

\subsection{Ash content and mineral composition}

Ash was determined following AOAC 923.03 method. Freeze-dried sample (2 g) was incinerated in muffle furnace for $24 \mathrm{~h}$ at $550{ }^{\circ} \mathrm{C}$, and white ashes were gravimetrically 
quantified (Horwitz and Latimer, 2005). The residue of incineration was recovered by the method of Rezaaiyan and Nikdel (1990).

$\mathrm{Fe}, \mathrm{Cu}, \mathrm{Zn}, \mathrm{Mn}, \mathrm{Ni}$ and $\mathrm{Cd}$ were measured directly at the appropriate wavelength for each element. The quantification of $\mathrm{K}, \mathrm{Ca}, \mathrm{Na}, \mathrm{Mg}$ was done after a decimal dilution (v/v), one $\mathrm{mL}$ of sample solution was mixed with $2 \mathrm{~mL} \mathrm{LaCl}_{2}(1.8 \%$, w/v) and $7 \mathrm{~mL}$ of deionized water for $\mathrm{Ca}$ and $\mathrm{Mg}$ determination, and another $1 \mathrm{~mL}$ was added to $2 \mathrm{~mL} \mathrm{CsCl}_{2}(0.2 \%$, w/v) and $7 \mathrm{~mL}$ of deionized water for $\mathrm{Na}$ and $\mathrm{K}$ determination. Calibration curves were plotted using standard solutions of each element. The measurement was performed using a Solaar M6 Series atomic absorption spectrometer (Thermo Fisher Scientific, Waltham, USA) (Horwitz and Latimer, 2005).

\subsection{Meteorological data}

Meteorological data (precipitation and temperature), at the study sites, are provided by the National Agency of Hydraulic Resources (ANRH). Weather-related parameters were shown by season throughout the reproductive cycle of the species from flowering time in the previous autumn to harvest time at the following year. Ombrothermic diagrams (Gaussen, 1954; Walter and Leith, 1960) of 2012 and 2013 are shown in Figure 1 and aridity class of each region was determine by aridity index (AI) calculation (de Martonne, 1926).

\subsection{Statistical analysis}

All analytical methods applied were previously validated for linearity, sensitivity, accuracy and precision in the range of the contents found in the samples, according to international standards of AOAC (Horwitz, 2002). All the analytical procedures were carried out in triplicate, including extraction processes and equipment calibration. Analysis of variance (ANOVA) followed by the Tukey's honestly significant difference (HSD) at 95\% confidence level and a multivariate data analysis by principal component analysis (PCA) were performed using XIStat software (Addinsoft, Paris, France). Three samples were analyzed for each area and harvesting season and triplicate data were taken for each parameter and sample. All the results were expressed as means $\pm \mathrm{SD}$ (standard deviations).

\section{Results and discussion}

\subsection{Morphological parameters}

Fruit description is often necessary in horticulture research for a range of different purposes like cultivars descriptions and selection (Beyer et al., 2002; Moreda et al., 2012). Fruit size and shape is an important quality trait of fruit in a commercial purpose (Chang et al., 2014) and in particular fruit size affects the acceptance of consumer. Moreover the fruit size can affect the chemical composition and the sensory characteristic of the fruit (Moreda $e t$ al., 2012; Prudent et al., 2014). 
The obtained weight of the A. unedo berries was between 1.66 and $12.46 \mathrm{~g}$ with an average weight of $5.87 \mathrm{~g}$. In this context, Sulusoglu et al. (2011) and Celikel et al. (2008) found the weight of Turkish A. unedo fruits were between 1.13-6.46 g and 3.09-11.08 g, respectively.

The length and diameter of harvested fruits were between 11.20-29.51 mm and 14.68$31.13 \mathrm{~mm}$ with average values of 21.24 and $22.83 \mathrm{~mm}$, respectively. This lead to a fruit shape index (FSI) value between $0.68-1.28$ with an average of 0.94 . The study of the geometrical characteristic revealed three fruit shapes: round shape $(0.9<\mathrm{FSI}<1.1)$, elongated shape $($ FSI $>1.1)$ and flat shape (FSI $<0.9)$. The FSI frequency distribution shows that fruits from different areas tended to have a round shape at $51.6 \%$ and a flat shape at $40.3 \%$ (Figure 2 and Table 1).

The comparison of fruit size and shape of each sampling area alone over the harvesting seasons showed that the fruits weight in each sampling area was significantly affected by the harvesting seasons (Table 1). In AD and MD, fruits presented higher average weight in 2013; but in SK and BM, higher fruit weights were obtained in 2012. It appears that the fruit weight was affected by the amount of annual rainfall of $\mathrm{AD}, \mathrm{BM}$ and MD (Figure 1). Annual precipitations in 2013 of $\mathrm{AD}(1,049.5 \mathrm{~mm})$ and $\mathrm{MD}(818 \mathrm{~mm})$ were higher than those recorded in 2012 (780 and $783 \mathrm{~mm}$, respectively), which induces higher fruit weights. Moreover, the same happens in the case of BM fruits, since summer rainfall of BM in 2012 (81.6 mm) were twofold higher than those of 2013 (41.6 mm) (Table S2, supplementary data). Molina et al. (2011) reported that fruit weight seemed to be particularly affected by summer drought.

Related to fruit weight, length and diameter were also higher for the fruits from AD and MD in 2013 than in 2012. The fruit shape (FSI) was the same over the two harvesting seasons for fruits from $\mathrm{AD}$, indicating higher size in 2013, but similar shape. On the contrary, it was found that fruits from BM showed slightly higher length and diameter in 2012, but no significant differences in length, diameter and FSI over the seasons (Table 1).

The alternate bearing of $A$. unedo fruits (weight, length and diameter) of the four studied areas over the two harvesting seasons was observed (Table 1). According to the literature, this phenomenon affects most fruit, nut and forest trees worldwide (Krasniqi et al., 2013) and it has been reported previously in citrus fruits (Combrink et al., 2013; Martínez-Fuentes et al., 2013; Monerri et al., 2011; Nebauer et al., 2014), apple fruits (Hehnen et al., 2012; Tromp, 1990) and date palm (Pillay et al., 2005).

\section{$3.2 \mathrm{pH}$ and titratable acidity}

The obtained acidic $\mathrm{pH}$ values were similar to those found in the Spanish strawberry-tree fruits (González et al., 2011; Ruiz-Rodríguez et al., 2011) and they were stable over sampling area and harvesting seasons with an average value of 3.43 (Table 2). Unlike to the results of the titratable acidity obtained by Ruiz-Rodríguez et al. (2011), minor fluctuations were observed in the present study, with values between 6.16 to $8.35 \mathrm{~g}$ of malic acid equivalents 
$\mathrm{kg}^{-1}$ of fruit (Table 2). These results were similar to titratable acidity of Turkish fruits (Celikel et al., 2008). The low $\mathrm{pH}$ value can have a big advantage for an industrial use of these fruits in manufacturing of juice, jam and jelly.

\subsection{Moisture content}

Water is a major constituent of most food products and plays an important role in food technology. Moreover, it is necessary to know the moisture content for calculations of the nutritional value of foods (Bradley, 2010). The moisture content of $A$. unedo fruits ranged from 637.3 to $741.3 \mathrm{~g} \mathrm{~kg}^{-1}$ (Table 2). These results showed an average value of moisture content $\left(709.4 \pm 36.7 \mathrm{~g} \mathrm{~kg}^{-1}\right)$ higher than the average value $\left(575.0 \mathrm{~g} \mathrm{~kg}^{-1}\right)$ reported by Tardío et al. (2016) with large variation range (427.0-721.0 $\mathrm{g} \mathrm{kg}^{-1}$ ) against values obtained in present study, with lower fluctuations (Table 2). Moisture content did not correlate to precipitation, which means that, as explained, more annual rainfall may be related to higher fruit size, but not just moisture accumulation.

\subsection{Total available carbohydrate}

The obtained TAC was the most important constituent after moisture content and the values were between 126.8 to $189.3 \mathrm{~g} \mathrm{~kg}^{-1}$, with higher content for 2012 than 2013 (Table 2). Ruiz-Rodríguez et al. (2011) showed a mean value of TAC in Spanish A. unedo fruits of $235.5 \mathrm{~g} \mathrm{~kg}^{-1}$, which is higher to the average value $\left(139.3 \mathrm{~g} \mathrm{~kg}^{-1}\right)$ of present study. Indeed, this result can be related to the difference in moisture content between two studies. In any case, TAC are about $50 \%$ of dry matter of these fruits, contributing to the energy value of these fruits.

\subsection{Soluble sugars}

Fructose and glucose constitute the total soluble sugars for all samples with range of 55.2 to $84.4 \mathrm{~g} \mathrm{~kg}^{-1}$ and 29.0 to $52.4 \mathrm{~g} \mathrm{~kg}^{-1}$ (Table 2), which globally represents 39.62 to 60.59 and 20.82 to $37.62 \%$ of TAC, respectively; the difference would correspond to starch. The most significant variations in soluble sugar contents were observed between harvesting seasons particularly in $\mathrm{AD}$ and MD samples (Table 2).

The ratio glucose/fructose was in the range of 0.55 to 0.65 , with low fluctuations comparing with the results of Ruiz-Rodríguez et al. (2011). The predominance of fructose in A. unedo fruits was confirmed in all previous studies (Ayaz et al., 2000; Barros et al., 2010; Ruiz-Rodríguez et al., 2011; Vidrih et al., 2013), unlike to other fruits (Kubola et al., 2011). Barros et al. (2010) and Ruiz-Rodríguez et al. (2011) found a higher soluble sugars content in Portuguese and Spanish A. unedo fruits respectively, but Serçe et al. (2010) showed lower level in Turkish fruits than those herein presented. In addition, some literatures reported the sucrose (Ayaz et al., 2000; Barros et al., 2010; Ruiz-Rodríguez et al., 2011) and maltose (Ayaz et al., 2000) presence in A. unedo fruits, which are absent in all studied samples. The absence of sucrose is explained by the possibility of its hydrolysis into monosaccharides during fruits ripening. 
The presence of fructose as predominant sugar, and glucose as the second one, both of them in levels higher than $80 \mathrm{~g} \mathrm{~kg}^{-1}$ in the fruits (fresh basis) explain the sweet taste of them (as fructose is sweeter than glucose and even sucrose), as well as their high sensitivity to alcoholic fermentation due to the presence of yeasts growing at acidic $\mathrm{pH}$ such as 3.4-3.5 found in the fruits.

Soluble sugars/titratable acidity ratio (SS/TA) is correlated with quality acceptance of consumers and maturity stage evaluation of many fruits (Jayasena and Cameron, 2008). However, to our knowledge there is no recommended minimum value for strawberry-tree fruits, unlike citrus fruit and grape (Kader, 1999). SS/TA ratio was ranging from 10.8 to 18.7 and significant differences were found between harvesting seasons excepted for the samples of BM.

\subsection{Dietary fiber}

Total dietary fiber (TDF) was present at values ranging from 92.8 to $141.3 \mathrm{~g} \mathrm{~kg}^{-1}$. Insoluble dietary fiber (IDF) was ranging between 80.5 to $122.3 \mathrm{~g} \mathrm{~kg}^{-1}$, representing 82.9 to $86.7 \%$ of TDF, and the results showed significant variability over areas and harvesting seasons except for the BM samples (Table 2). Ruiz-Rodríguez et al. (2011) found that TDF of Spanish A. unedo fruits were between $100-222 \mathrm{~g} \mathrm{~kg}^{-1}$ and IDF was also predominant as the results obtained in this study.

According to these results, and despite natural variations, fiber content in Algerian strawberry-tree fruits was always over $6 \mathrm{~g} / 100 \mathrm{~g}$. This means that strawberry-tree fruits from North Africa could be considered as an excellent source of fiber for human populations, which is of great importance in the light of the fact that modern diets are often lacking of dietary fiber, and that occidental diets are nowadays lacking in dietary fiber. Considering the recommendation of fiber intake, which are 21-38 $\mathrm{g} \mathrm{day}^{-1}$ for adults (Trumbo et al., 2002), the intake of $100 \mathrm{~g}$ of strawberry-tree fruits could provide $30-44 \%$ of daily recommendation of fiber; and according to European Regulations it could be considered under the approved mention "high in fiber" (European Parliament and Council, 2011).

\subsection{Protein content}

Protein content varied from 22.6 to $35.5 \mathrm{~g} \mathrm{~kg}^{-1}$ (Table 2). These results were higher than those obtained by Ruiz-Rodríguez et al. (2011) $\left(8.9 \mathrm{~g} \mathrm{~kg}^{-1}\right)$, but in the same range of those obtained in Turkish (33.6 $\mathrm{g} \mathrm{kg}^{-1}$ ) (Özcan and Hacıseferoğulları, 2007) and Galician fruits (31.8 $\mathrm{g} \mathrm{kg}^{-1}$ ) (González et al., 2011). The fruit of 2012 season presented significantly higher protein content than those of 2013 season, except for MD samples in which there was no significant difference over the harvesting seasons.

\subsection{Lipid content}

Lipid content varied from 5.1 to $8.9 \mathrm{~g} \mathrm{~kg}^{-1}$ and showed significant seasonal variability for the samples of $\mathrm{AD}, \mathrm{BM}$ and MD but no significant difference of those of SK. This result is in 
accordance with the lipid content of Portuguese (Barros et al., 2010) and Spanish (RuizRodríguez et al., 2011) A. unedo fruits with 5.5 and 5.0-7.8 $\mathrm{g} \mathrm{kg}^{-1}$, respectively, but lower (21.0 $\mathrm{g} \mathrm{kg}^{-1}$ ) than those of the Turkish A. unedo fruits (Özcan and Haciseferoğullar1, 2007). It is well known, altitude growth could affect fruits composition (Brat et al., 2004). In present study, over all studied characteristics there is only lipid content, which is subjected to altitude effect. Thus, significant differences have been found between high altitude sites (AD and MD) and low altitude sites (BM and SK).

\subsection{Fatty acids composition}

Twenty-six individual fatty acids were identified and quantified (Table 3), and the chromatographic profile was characterized by a high content of unsaturated fatty acids (82.4$89.1 \%$ ), which the $\alpha$-linolenic acid was the highest amount, with values from 30.5 to $45.1 \%$, followed by linoleic acid (22.27-26.89\%) and oleic acid (17.48-29.92\%). For saturated fatty acids, palmitic acid (7.22-11.4\%) was the highest, followed by stearic acid (2.99-3.89\%). This fatty acids profile was similar to the Portuguese (Barros et al., 2010; Oliveira et al., 2011a) and Spanish (Morales et al., 2013) strawberry-tree fruits profile. $\alpha$-Linolenic acid and linoleic acid are essential fatty acids for human body and must be supplied by diet (Voortman et al., 2015), to fulfil essential human functions, including maintenance of the skin water barrier, optimal brain function, regulation of the immune system and reproduction (Babirekere-Iriso et al., 2016) and a number of studies, specifically, demonstrate that high intakes of PUFA of both the $\omega 3$ and $\omega 6$ series are protective against cardiovascular diseases (Dunbar et al., 2014; Machado et al., 2012; Marangoni et al., 2014; Siegel and Ermilov, 2012). From this point of view, strawberry-tree fruits with a high content of PUFA, low level of SFA, and $\omega 3 / \omega 6$ ratio superior to 1 , can promote health benefits.

\subsection{Ash content}

Ash content ranged from 5.3 to $8.8 \mathrm{~g} \mathrm{~kg}^{-1}$ and the highest content was obtained in BM fruits of 2012 (Table 2). Significant differences were found in ash content of BM and MD fruits over the harvesting seasons, but no significant difference were found in AD and SK fruits over harvesting seasons. Other authors such as González et al. (2011), Ruiz-Rodríguez et al. (2011) and Barros et al. (2010) reported similar ash content in A. unedo fruits (5.6, 6.8, and $6.9 \mathrm{~g} \mathrm{~kg}^{-1}$, respectively) while Özcan and Hacıseferoğulları (2007) reported higher ash content $\left(28.2 \mathrm{~g} \mathrm{~kg}^{-1}\right)$.

\subsection{Mineral composition}

Macro-elements (K, Na, Ca and $\mathrm{Mg}$ ) and microelement (Fe, $\mathrm{Cu}, \mathrm{Mn}, \mathrm{Zn}, \mathrm{Ni}$ and $\mathrm{Cd}$ ) contents showed significant differences between sampling areas and harvesting seasons (Table 4). Mineral content is one of the most variable parameter in plant food composition, due to the influence of soil composition and other environmental conditions on it (de Souza et al., 2014; Nyanga et al., 2013). According with this, mineral elements content in NorthAfrican A. unedo fruits showed variation that in some cases duplicate (eg. $\mathrm{Na}, \mathrm{Mg}, \mathrm{Fe}, \mathrm{Zn}$ ) or triplicate (eg. K, $\mathrm{Ca}, \mathrm{Cu}$ ) values; in the case of $\mathrm{Mn}$ the variations are even wider. Often, 
variations in composition between fruits obeys to the presence of water; however, in this case, when calculating the results as dry basis, the same tendency of variation was found for the composition of the fruits.

For the macro-elements, $\mathrm{K}$ showed the highest content in all the analyzed samples, followed by $\mathrm{Ca}, \mathrm{Mg}$ and $\mathrm{Na}$, with the range from 1,529 to 3,486, 315.0 to 959.4, 115.3 to 277.9 , and 126.8 to $226.7 \mathrm{mg} \mathrm{kg}^{-1}$, respectively (Table 4). BM and MD have calcareous soils (rich in calcium carbonate), this could explain the high Ca content of their fruits compared to those of AD and SK. These results were similar to the Spanish (Ruiz-Rodríguez et al., 2011) and Turkish (Özcan and Hacıseferoğulları, 2007) mineral composition. It has been reported that the $\mathrm{Ca}, \mathrm{Mg}$ and $\mathrm{K}$ have essential roles in bone, heart, muscle, nerve and immune systems maintenance (Nyanga et al., 2013).

For the microelements, Fe showed the highest content, followed by $\mathrm{Zn}, \mathrm{Cu}$ and $\mathrm{Mn}$. Fe amounts were ranging between 7.01 to $17.24 \mathrm{mg} \mathrm{kg}^{-1}$, which was higher than those of many cultivated fruits (strawberry, apple, peach and orange) (Souci et al., 1994), followed by Zn, $\mathrm{Cu}$ and $\mathrm{Mn}$ contents, respectively, with values between 2.30-4.63, 0.76-3.41 and 0.11-3.43 $\mathrm{mg} \mathrm{kg}^{-1}$ (Table 4). The microelement contents found in Turkish (Özcan and Hacıseferoğulları, 2007) and Spanish (Ruiz-Rodríguez et al., 2011) A. unedo fruits were similar to those found in our samples. The biological activities of microelements are strongly associated with the presence of unpaired electrons that allow their participation in redox reactions. Moreover, $\mathrm{Fe}, \mathrm{Mn}, \mathrm{Zn}$ are usually cofactors in enzymatic systems, $\mathrm{Cu}$ is necessary for the development of connective tissue, nerve coverings and bone, and $\mathrm{Mn}$ is associated with bone development (Fraga, 2005). They accomplish essential functions to maintaining human health. $\mathrm{Zn}$ is an antioxidant and anticarcinogen element necessary for human cellular functions (Turkdogan et al., 2003).

The sum of microelements and macro-elements for each area over the harvesting seasons showed the BM samples with higher mineral contents than those from MD, SK and AD (Table 4).

The contents of $\mathrm{Ni}$ and $\mathrm{Cd}$ were also investigated in the $A$. unedo fruits (Table 4). $\mathrm{Cd}$ is a toxic element and could be found in fruit mainly due to the environmental pollution (Hamurcu et al., 2010; Turkdogan et al., 2003). The samples of 2012 presented higher Ni content (1.98 $3.87 \mathrm{mg} \mathrm{kg}^{-1}$ ) than the Turkish $A$. unedo fruits (Özcan and Hacıseferoğulları, 2007) but Cd contents of the same samples $\left(0.02-0.03 \mathrm{mg} \mathrm{kg}^{-1}\right)$ were lower than those given by the same author. Ni and Cd could not be detected in the 2013 samples.

As nutrient levels may vary greatly because of genetic and environmental factors, the variability in food composition must be covered in Food Composition Data (Tardío et al., 2016). Thus, supplemental information depicts the results of average and range content of moisture, TAC, soluble sugars, TDF, protein, lipid, ash and mineral composition (Table S1).

\subsection{Multivariate data analysis}


A principal component analysis (PCA) was performed on moisture content, protein, TAC, fructose, glucose, total soluble sugar content, ash content, IDF, SDF and TDF. This is a multivariate analysis reducing the multidimensional structure of the data and providing a three-dimensional map for explaining the variance observed (Figure 3).

The first two components explained $78.67 \%$ of the total variability in the composition of fruit over the two harvest seasons. The first principal component $(59.23 \%$ of the total variance) was highly correlated with glucose, IDF, TDF and in minor degree with fructose and lipid while it was negatively correlated with moisture content. The second principal component (19.45\% of the total variance) was highly correlated with TAC and in minor degree with ash content. Moisture content was negatively correlated with protein, fructose, glucose, IDF, TDF and lipid content. IDF and TDF were more correlated with glucose than fructose; and glucose was highly correlated with fructose. Lipid content was correlated with fructose and glucose, while ash content and TAC were not correlated with any compound.

All the samples were plotted on the reduced space of the two principal components (Figure 3). As can be observed, fruits from AD, SK and BM of 2013 showed some similarities with high moisture content and low TAC. Fruits from AD of 2012 were mostly characterized by the first component with high TDF, IDF, glucose, lipid content and low moisture content. Moreover, fruits from BM of 2012 could be considered rich in TAC and ash content, while fruits from MD of 2012 had high moisture content and low content of TDF, IDF, fructose and glucose. Also, the PCA showed that the influence of seasonal variations were more relevant than the geographical effect on the chemical composition of studied strawberry-tree fruits, especially in those characteristics related to component 2 , which separate fruits harvested in 2012 (with higher TAC, ash and proteins) from those collected in 2013.

The first three components, of PCA performed on ash and mineral composition, explained $89.76 \%$ of the observed variance (Figure 4). K, Mg, Ni, Zn and ash were correlated to the first component; while the second components was highly correlated with $\mathrm{Mn}$ and negatively correlated with Na. Fruits harvested in 2013 were in the first and second quarter. However, those collected in 2012 were represented in the third and fourth quarter of the biplot (component 1 and component 2) (Figure 4). This data representation showed that seasonal variability affected also ash and mineral composition of the fruits more than geographical variability; this can be explained by the fact that ash and mineral composition were negatively correlated with moisture content.

The climate of the study sites is a Mediterranean climate characterized by a rainy and mild winter and a dry and hot summer (Table S2, supplementary data). Annual precipitations and annual mean temperature varied from 597.9 to 1090.2 and from 15 to $19.4{ }^{\circ} \mathrm{C}$, respectively (Figure 1). AI of AD, BM, MD and SK were 24.8, 38.1, 30.0 and 20.4 for 2012, respectively; and 36.7, 31.6, 32.8 and 28.7 for 2013, respectively (Table $S 3$, supplementary data). According to these results, MD and BM have a humid climate, while SK climate was sub-humid. AD climate varied from sub-humid to humid depending on interannual variations of rainfall and temperature. Annual rainfall of AD in 2013 were higher $(1,049.5 \mathrm{~mm})$ than 
those of $2012(728 \mathrm{~mm})$.

The short study period and the long period of fruit development from flowering to maturity do not allow a quantitative assessment of the effect of climate on the morphological and nutritional variability of strawberry-tree fruits. However, statistical treatment performed on morphological characteristics, precipitation and temperature (Fig. S1, supplementary data), showed some correlation between interannual climate fluctuations and the variables fruit weight, length, diameter and FSI. In this context, fruit weight was correlated with autumn temperature, mean annual temperature and summer precipitation; length was correlated with autumn precipitation, spring precipitation and mean annual precipitation; diameter was correlated with winter temperature, autumn temperature, mean annual temperature and summer precipitation. In addition, FSI presented a neat correlation with spring precipitation and was inversely correlated with winter temperature, autumn temperature and mean annual temperature. No other relevant correlations were found between climatologic conditions and fruit chemical components; natural variability is due to a complex number of factors (genetic and environmental) and it is not always well explained, only, through environmental conditions. However, this variability should be taken into account when studying fruit composition to know the range of variation of nutrients that should be expected in a given fruit.

\section{Conclusion}

The objective of morphological, physicochemical and nutritional characterization of $A$. unedo L. fruits from tell Atlas has been achieved. As natural variation were reflected in composition data, it can be seen that harvesting season had more influence on composition of fruits than location. The Algerian strawberry-tree fruits tended to have a round shape at $51.6 \%$ and a flat shape at $40.3 \%$, stable acidic $\mathrm{pH}$, titratable acidity with minor fluctuations, had rich contents of TAC with predominant soluble sugars (fructose and glucose), dietary fiber and proteins. Wide variations in mineral composition were found in the fruits. Twenty-six individual fatty acids were identified, mostly unsaturated fatty acids $(>82 \%)$, in which the $\alpha$ linolenic acid is the most abundant. For the mineral analysis, $\mathrm{K}$ and $\mathrm{Fe}$ showed the highest content in identified macro-elements and microelements, respectively, with high-level of Fe compared to other edible fruits.

In the light of the results obtained, the hypothesis that Algerian A. unedo fruits could be a healthy alternative for fruit production is confirmed, especially for their high content in fiber, which can be highlighted as a nutritional claim for this fruit, even taking into account natural variations. They are also, a source of water and the amount of soluble sugars provided make them a moderate source of quickly available energy; this kind of sources of energy are highly valuable for the human diet, since they provide very low fat (with a healthy profile) and the concomitant intake of minerals and other healthy nutrients. The obtained data can be incorporated to fruit composition databases to improve the representativity of the data about the nutritional potential of strawberry fruits.

In perspective, for better knowledge of Algerian A. unedo fruits, analyzes of vitamins, 
polyphenols, organic acids, antioxidant and antimicrobial activities, etc., are necessary to investigate the possibility of integrating this fruit in sustainable project to promote an economic development of the rural regions. Furthermore, breeding programs to improve fruit quality could promote the potential uses of these fruits in food industry.

\section{Acknowledgment}

The authors are grateful to the Algerian Ministry of Higher Education and Scientific Research for funding the study; to ALIMNOVA research group (UCMGR35/10A) for financial support and to the Foundation for Science and Technology (FCT, Portugal) for financial support to CIMO (Pest-OE/AGR/UI0690/2015) and L. Barros (SFRH/BPD/107855/2015).

\section{References}

Alarcão-E-Silva, M.L.C.M.M., Leitão, A.E.B., Azinheira, H.G., and Leitão, M.C.A. (2001). The Arbutus Berry: Studies on its Color and Chemical Characteristics at Two Mature Stages. Journal of Food Composition and Analysis 14, 27-35.

Allane, T., and Benamara, S. (2010). Activités antioxydantes de quelques fruits communs et sauvages d'Algérie. Phytothérapie 8, 171-175.

Ayaz, F.A., Kucukislamoglu, M., and Reunanen, M. (2000). Sugar, Non-volatile and Phenolic Acids Composition of Strawberry Tree (Arbutus unedo L. var. ellipsoidea) Fruits. Journal of Food Composition and Analysis 13, 171-177.

Babirekere-Iriso, E., Lauritzen, L., Mortensen, C.G., Rytter, M.J.H., Mupere, E., Namusoke, H., Michaelsen, K.F., Briend, A., Stark, K.D., Metherel, A.H., et al. (2016). Essential fatty acid composition and correlates in children with severe acute malnutrition. Clinical Nutrition ESPEN 11, e40-e46.

Barros, L., Carvalho, A.M., Morais, J.S., and Ferreira, I.C.F.R. (2010). Strawberry-tree, blackthorn and rose fruits: Detailed characterisation in nutrients and phytochemicals with antioxidant properties. Food Chemistry 120, 247-254.

Barros, L., Venturini, B.A., Baptista, P., Estevinho, L.M., and Ferreira, I.C. (2008). Chemical composition and biological properties of portuguese wild mushrooms: a comprehensive study. J Agric Food Chem 56, 3856-3862.

Beyer, M., Hahn, R., Peschel, S., Harz, M., and Knoche, M. (2002). Analysing fruit shape in sweet cherry (Prunus avium L.). Scientia Horticulturae 96, 139-150.

Bradley, R.L. (2010). Moisture and Total Solids Analysis. In Food Analysis, S.S. Nielsen, ed. (Boston, MA: Springer US), pp. 85-104.

Brat, P., Yahia, A., Chillet, M., Bugaud, C., Bakry, F., Reynes, M., and Brillouet, J.-M. (2004). Influence of cultivar, growth altitude and maturity stage on banana volatile compound composition. Fruits 59, 75-82.

Brewer, M.T., Lang, L., Fujimura, K., Dujmovic, N., Gray, S., and van der Knaap, E. (2006). Development of a controlled vocabulary and software application to analyze fruit shape variation in tomato and other plant species. Plant physiology 141, 15-25.

Caudullo, G., Welk, E., and San-Miguel-Ayanz, J. (2017). Chorological maps for the main European woody species. Data in brief 12, 662-666. 
Celikel, G., Demirsoy, L., and Demirsoy, H. (2008). The strawberry tree (Arbutus unedo L.) selection in Turkey. Scientia Horticulturae 118, 115-119.

Chang, Y., Sun, R., Sun, H., Zhao, Y., Han, Y., Chen, D., Wang, Y., Zhang, X., and Han, Z. (2014). Mapping of quantitative trait loci corroborates independent genetic control of apple size and shape. Scientia Horticulturae 174, 126-132.

Combrink, N.K., Labuschagne, M.T., and Bijzet, Z. (2013). Variation of fruit size and shape in Kiyomi tangor families. Scientia Horticulturae 162, 357-364.

Cornara, L., La Rocca, A., Marsili, S., and Mariotti, M.G. (2009). Traditional uses of plants in the Eastern Riviera (Liguria, Italy). Journal of Ethnopharmacology 125, 16-30.

de Martonne, E. (1926). Une nouvelle function climatologique: L'indice d'aridité. Meteorologie 2, 449-459.

de Souza, V.R., Pereira, P.A., da Silva, T.L., de Oliveira Lima, L.C., Pio, R., and Queiroz, F. (2014). Determination of the bioactive compounds, antioxidant activity and chemical composition of Brazilian blackberry, red raspberry, strawberry, blueberry and sweet cherry fruits. Food Chemistry 156, 362-368.

Dunbar, B.S., Bosire, R.V., and Deckelbaum, R.J. (2014). Omega 3 and omega 6 fatty acids in human and animal health: an African perspective. Molecular and cellular endocrinology 398, 69-77.

El-Hilaly, J., Hmammouchi, M., and Lyoussi, B. (2003). Ethnobotanical studies and economic evaluation of medicinal plants in Taounate province (Northern Morocco). Journal of Ethnopharmacology 86, 149-158.

European Parliament and Council (2011). Regulation (EU) No 1169/2011 of the European Parliament and of the Council of 25 October 2011 on the provision of food information to consumers. Official Journal of the European Union, 22112011: L304/18-L304/63.

Fraga, C.G. (2005). Relevance, essentiality and toxicity of trace elements in human health. Molecular Aspects of Medicine 26, 235-244.

Gaussen, H. (1954). Théorie et classification des climats et microclimats. VIIIe Congrès international de botanique: 2-14 July 1954, 125-130.

González, E.A., Agrasar, A.T., Castro, L.M.P., Fernández, I.O., and Guerra, N.P. (2011). Solid-state fermentation of red raspberry (Rubus ideaus L.) and arbutus berry (Arbutus unedo L.) and characterization of their distillates. Food Research International 44, 14191426.

Greenfield, H., and Southgate, D.A. (2003). Food composition data: production, management, and use (Food and Agriculture Organization).

Hamurcu, M., Ozcan, M.M., Dursun, N., and Gezgin, S. (2010). Mineral and heavy metal levels of some fruits grown at the roadsides. Food and Chemical Toxicology 48, 17671770 .

Hehnen, D., Hanrahan, I., Lewis, K., McFerson, J., and Blanke, M. (2012). Mechanical flower thinning improves fruit quality of apples and promotes consistent bearing. Scientia Horticulturae 134, 241-244.

Horwitz, W. (2002). AOAC guidelines for single laboratory validation of chemical methods for dietary supplements and botanicals (Gaithersburg, MD, USA: AOAC International).

Horwitz, W., and Latimer, G.W. (2005). Official Methods of Analysis of AOAC International, 18th edn (Gaitheresburg, MD, USA: AOAC International). 
Jayasena, V., and Cameron, I. (2008). ${ }^{\circ}$ Brix/acid ratio as a predictor of consumer acceptability of Crimson Seedless table grapes. J Food Quality 31, 736-750.

Jones, A., Breuning-Madsen, H., Brossard, M., Dampha, A., Deckers, J., Dewitte, O., Gallali, T., Hallett, S., Jones, R., Kilasara, M., et al. (2013). Soil atlas of Africa (Luxembourg: European Commission, Publications Office of the European Union ).

Kader, A.A. (1999). Fruit maturity, ripening, and quality relationships. Paper presented at: International Symposium Effect of Pre-and Postharvest factors in Fruit Storage Acta Horticultura 485, 203-208 (Acta Horticultura).

Krasniqi, A.L., Damerow, L., Kunz, A., and Blanke, M.M. (2013). Quantifying key parameters as elicitors for alternate fruit bearing in cv. 'Elstar' apple trees. Plant Science $212,10-14$.

Kubola, J., Siriamornpun, S., and Meeso, N. (2011). Phytochemicals, vitamin C and sugar content of Thai wild fruits. Food Chemistry 126, 972-981.

Leonti, M., Casu, L., Sanna, F., and Bonsignore, L. (2009). A comparison of medicinal plant use in Sardinia and Sicily-De Materia Medica revisited? Journal of Ethnopharmacology 121, 255-267.

Machado, R.M., Nakandakare, E.R., Quintao, E.C., Cazita, P.M., Koike, M.K., Nunes, V.S., Ferreira, F.D., Afonso, M.S., Bombo, R.P., Machado-Lima, A., et al. (2012). Omega-6 polyunsaturated fatty acids prevent atherosclerosis development in LDLr-KO mice, in spite of displaying a pro-inflammatory profile similar to trans fatty acids. Atherosclerosis $224,66-74$.

Maieves, H.A., Ribani, R.H., Morales, P., and Sánchez-Mata, M.d.C. (2015). Evolution of the nutritional composition of Hovenia dulcis Thunb. pseudofruit during the maturation process. Fruits 70, 181-187.

Marangoni, F., Novo, G., Perna, G., Perrone Filardi, P., Pirelli, S., Ceroti, M., Querci, A., and Poli, A. (2014). Omega-6 and omega-3 polyunsaturated fatty acid levels are reduced in whole blood of Italian patients with a recent myocardial infarction: the AGE-IM study. Atherosclerosis 232, 334-338.

Martínez-Fuentes, A., Mesejo, C., Muñoz-Fambuena, N., Reig, C., González-Mas, M.C., Iglesias, D.J., Primo-Millo, E., and Agustí, M. (2013). Fruit load restricts the flowering promotion effect of paclobutrazol in alternate bearing Citrus spp. Scientia Horticulturae $151,122-127$.

Mhamdi Takrouni, M., Ben El Haj Ali, I., Messaoued, C., and Boussaid, M. (2012). Genetic variability of Tunisian wild strawberry tree (Arbutus unedo L.) populations interfered from isozyme markers. Scientia Horticulturae 146, 92-98.

Mhamdi Takrouni, M., and Boussaid, M. (2010). Genetic diversity and population's structure in Tunisian strawberry tree (Arbutus unedo L.). Scientia Horticulturae 126, 330-337.

Molina, M., Pardo-De-Santayana, M., Aceituno, L., Morales, R., and Tardio, J. (2011). Fruit production of strawberry tree (Arbutus unedo L.) in two Spanish forests. Forestry 84, 419-429.

Monerri, C., Fortunato-Almeida, A., Molina, R.V., Nebauer, S.G., García-Luis, A., and Guardiola, J.L. (2011). Relation of carbohydrate reserves with the forthcoming crop, flower formation and photosynthetic rate, in the alternate bearing 'Salustiana' sweet orange (Citrus sinensis L.). Scientia Horticulturae 129, 71-78. 
Morales, P., Ferreira, I.C.F.R., Carvalho, A.M., Fernández-Ruiz, V., Sánchez-Mata, M.C., Cámara, M., Morales, R., and Tardío, J. (2013). Wild edible fruits as a potential source of phytochemicals with capacity to inhibit lipid peroxidation. Eur J Lipid Sci Tech 115, 176-185.

Moreda, G.P., Muñoz, M.A., Ruiz-Altisent, M., and Perdigones, A. (2012). Shape determination of horticultural produce using two-dimensional computer vision - A review. Journal of Food Engineering 108, 245-261.

Nebauer, S.G., Renau-Morata, B., Lluch, Y., Baroja-Fernandez, E., Pozueta-Romero, J., and Molina, R.V. (2014). Influence of crop load on the expression patterns of starch metabolism genes in alternate-bearing citrus trees. Plant physiology and biochemistry 80 , 105-113.

Nyanga, L.K., Gadaga, T.H., Nout, M.J., Smid, E.J., Boekhout, T., and Zwietering, M.H. (2013). Nutritive value of masau (Ziziphus mauritiana) fruits from Zambezi Valley in Zimbabwe. Food Chemistry 138, 168-172.

Oliveira, I., Baptista, P., Malheiro, R., Casal, S., Bento, A., and Pereira, J.A. (2011a). Influence of strawberry tree (Arbutus unedo L.) fruit ripening stage on chemical composition and antioxidant activity. Food Research International 44, 1401-1407.

Oliveira, I., Guedes de Pinho, P., Malheiro, R., Baptista, P., and Pereira, J.A. (2011b). Volatile profile of Arbutus unedo L. fruits through ripening stage. Food Chemistry 128, 667-673.

Osborne, D., and Voogt, P. (1986). Análisis de los nutrientes de los alimentos (Zaragoza: Acribia).

Özcan, M.M., and Hacıseferoğulları, H. (2007). The Strawberry (Arbutus unedo L.) fruits: Chemical composition, physical properties and mineral contents. Journal of Food Engineering 78, 1022-1028.

Pallauf, K., Rivas-Gonzalo, J.C., del Castillo, M.D., Cano, M.P., and de Pascual-Teresa, S. (2008). Characterization of the antioxidant composition of strawberry tree (Arbutus unedo L.) fruits. Journal of Food Composition and Analysis 21, 273-281.

Pillay, A.E., Williams, J.R., El Mardi, M.O., Hassan, S.M., and Al-Hamdi, A. (2005). Boron and the alternate-bearing phenomenon in the date palm (Phoenix dactylifera). Journal of Arid Environments 62, 199-207.

Prudent, M., Dai, Z.W., Génard, M., Bertin, N., Causse, M., and Vivin, P. (2014). Resource competition modulates the seed number-fruit size relationship in a genotype-dependent manner: A modeling approach in grape and tomato. Ecological Modelling 290, 54-64.

Rezaaiyan, R., and Nikdel, S. (1990). A comparison of mineral extraction techniques of Citrus juices as analyzed by inductively coupled plasma atomic emission spectrometry. $\mathrm{J}$ Food Sci 55, 1359-1360.

Ruiz-Rodríguez, B.M., Morales, P., Fernández-Ruiz, V., Sánchez-Mata, M.-C., Cámara, M., Díez-Marqués, C., Pardo-de-Santayana, M., Molina, M., and Tardío, J. (2011).

Valorization of wild strawberry-tree fruits (Arbutus unedo L.) through nutritional assessment and natural production data. Food Research International 44, 1244-1253.

Ruiz-Rodríguez, B.M., Sánchez-Moreno, C., De Ancos, B., Cortes Sánchez-Mata, M.D., Fernández-Ruiz, V., Cámara, M., and Tardío, J. (2014a). Wild Arbutus unedo L. and Rubus ulmifolius Schott fruits are underutilized sources of valuable bioactive compounds with antioxidant capacity. Fruits 69, 435-448. 
Ruiz-Rodríguez, M.B., de Ancos, B., Sánchez-Moreno, C., Fernández-Ruiz, V., de Cortes Sánchez-Mata, M., Cámara, M., and Tardío, J. (2014b). Wild blackthorn (Prunus spinosa L.) and hawthorn (Crataegus monogyna Jacq.) fruits as valuable sources of antioxidants. Fruits 69, 61-73.

Sánchez-Mata, M.C., Peñuela-Teruel, M.J., Cámara-Hurtado, M., Díez-Marqués, C., and Torija-Isasa, M.E. (1998). Determination of Mono-, Di-, and Oligosaccharides in Legumes by High-Performance Liquid Chromatography Using an Amino-Bonded Silica Column. J Agric Food Chem 46, 3648-3652.

Sánchez-Mata, M.d.C., and Tardío, J. (2016). Mediterranean Wild Edible Plants: Ethnobotany and Food Composition Tables (New York: Springer).

Serçe, S., Özgen, M., Torun, A.A., and Ercişli, S. (2010). Chemical composition, antioxidant activities and total phenolic content of Arbutus andrachne L. (Fam. Ericaceae) (the Greek strawberry tree) fruits from Turkey. Journal of Food Composition and Analysis 23, 619623.

Siegel, G., and Ermilov, E. (2012). Omega-3 fatty acids: benefits for cardio-cerebro-vascular diseases. Atherosclerosis 225, 291-295.

Souci, S.W., Fachmann, W., and Kraut, H. (1994). Food Composition and Nutrition Tables, 5th edn (Stuttgart: Medpharm Scientific Publishers).

Sulusoglu, M., Cavusoglu, A., and Erkal, S. (2011). Arbutus unedo L. (Strawberry tree) selection in Turkey Samanli mountain locations. Journal of Medicinal Plants Research 5, 3545-3551.

Tardío, J., Sánchez-Mata, M.d.C., Morales, R., Molina, M., García-Herrera, P., Morales, P., Díez-Marquéz, C., Fernández-Ruiz, V., Cámara, M., Pardo-de-Santayana, M., et al. (2016). In Mediterranean Wild Edible Plants : Ethnobotany and Food Composition, M.d.C. Sánchez-Mata, and J. Tardío, eds. (New York: Springer), pp. 271-470.

Tromp, J. (1990). Fruit shape in apple under various controlled environment conditions. Scientia Horticulturae 43, 109-115.

Trumbo, P., Schlicker, S., Yates, A.A., and Poos, M. (2002). Dietary Reference Intakes for Energy, Carbohydrate, Fiber, Fat, Fatty Acids, Cholesterol, Protein and Amino Acids. J Am Diet Assoc 102, 1621-1630.

Turkdogan, M.K., Kilicel, F., Kara, K., Tuncer, I., and Uygan, I. (2003). Heavy metals in soil, vegetables and fruits in the endemic upper gastrointestinal cancer region of Turkey. Environmental toxicology and pharmacology 13, 175-179.

Vidrih, R., Hribar, J., Prgomet, Ž., and Poklar Ulrih, N. (2013). The physico-chemical properties of strawberry tree (Arbutus unedo L.) fruits. Croatian Journal of Food Science and Technology 5, 29-33.

Voortman, T., van den Hooven, E.H., Braun, K.V.E., van den Broek, M., Bramer, W.M., Chowdhurry, R., and Franco, O.H. (2015). Effects of polyunsaturated fatty acid intake and status during pregnancy, lactation, and early childhood on cardiometabolic health: A systematic review. Progress in Lipid Research 59, 67-87.

Walter, H., and Leith, H. (1960). Klimadiagram-Weltatlas (Jena: Fischer Verlag). 